\title{
Implikasi Hukum Terhadap Notaris Yang Memberikan Jasa Kenotariatan Di Luar Kewenangannya
}

\author{
Dondy Permana Putra \\ Magister Kenotariatan Fakultas Hukum Universitas Islam Indonesia \\ Jln. Cik Di Tiro No. 1, Yogyakarta, 55223 \\ dondypermanaputra15@gmail.com
}

\begin{abstract}
This study examines the legal implications for notaries who provide notary services beyond their authority, in which case the notary is an extension of the state, and in the case of a notary's accountability, it is the primary issue considering the deed they make is a strong written evidence. Hence, the first problem arises is the legal implications and accountability of the notary for their position in carrying out matters beyond their authority. Second, what is the Regional Supervisory Council (MPD)'s view of notaries who carry out matters beyond their authority. The results conclude that first, if a notary has committed a violation, they will receive civil and administrative sanctions in the form of compensation, temporary dismissal from their position or disrespectful dismissal. Second, the implementation of supervision and coaching that has been carried out by the Notary Supervisory Council must prioritize communication between the Central Supervisory Council (MPP), the Provincial Supervisory Council (MPW), the Regional Supervisory Council (MPD) to the Notary themselves is very important to avoid miscommunication and to create good synergy in the implementation of supervision carried out by the Supervisory Council.
\end{abstract}

Key Words: Authorities; implications; Notary Supervisory Council

\begin{abstract}
Abstrak
Penelitian ini meneliti tentang implikasi hukum terhadap notaris yang memberikan jasa kenotariatan di luar kewenangannya, dimana dalam hal ini Notaris merupakan perpanjangan tangan dari negara,dan dalam masalah pertanggungjawaban seorang Notaris, merupakan hal yang utama mengingat akta yang ia buat merupakan alat bukti tertulis bukti yang kuat.Berdasarkan hal tersebut, muncul permasalahan yang pertama, implikasi hukum dan pertanggungjawaban notaris terhadap jabatannya dalam melaksanakan hal yang berada diluar kewenangannya. Kedua, bagaimana pandangan MPD terhadap notaris yang menjalankan hal yang berada diluar kewenangannya. Hasil penelitian ini menyimpulkan bahwa pertama, apabila Notaris telah melakukan pelanggaran, maka akan mendapatkan sanksi perdata dan sanksi administrasi yang bisa berbentuk ganti rugi, pemberhentian sementara dari jabatannya ataupun diberhentikan secara tidak hormat. Kedua, Penerapan pengawasan dan pembinaan yang telah dilakukan oleh Majelis Pengawas Notaris harus mengedepankan komunikasi antar Majelis Pengawas Pusat (MPP), Majelis Pengawas Wilayah (MPW), Majelis Pengawas Daerah (MPD) hingga ke Notaris itu sendiri sangat penting guna menghindari miskomunikasi serta untuk menciptakan sinergi yang baik dalam penerapan pengawasan yang dilakukan oleh Majelis Pengawas.
\end{abstract}

Kata-kata Kunci: Implikasi; Majelis Pengawas Notaris; wewenang 


\section{Pendahuluan}

Notaris adalah pejabat umum yang berwenang untuk membuat akta otentik dan kewenangan lainya, hal tersebut diatur dalam Pasal 1 ayat (1) UndangUndang Nomor 2 Tahun 2014 tentang Perubahan atas Undang-Undang Nomor 30 Tahun 2004 tentang Jabatan Notaris (UUJN). Jabatan Notaris tidak ditempatkan di lembaga yudikatif, eksekutif maupun legislatif. ${ }^{1}$ Tidak hanya dalam hal perjanjian, peranan Notaris juga dibutuhkan oleh masyarakat dalam pembuatan akta otentik. Dimana Notaris yang merupakan perpanjangan tangan dari negara,negara memberikan kepercayaan kepada Notaris untuk menjalankan sebagian urusan atau tugas negara, khususnya dalam bidang perdata. Untuk itu, dengan adanya keberadaan Notaris, negara pun menjawab kebutuhan masyarakat akan bantuan hukum yang netral dan berimbang sehingga melindungi kepentingan hukum masyarakat terlebih dalam hal keperdataan, dimana hampir setiap sisi dan elemen masyarakat bersentuhan secara langsung dengan keperdataan di setiap kegiatannya sehari hari.

Notaris diharapkan dapat memberikan pelayanan hukum kepada masyarakat serta memberikan pelayanan hukum kepada masyarakat dan juga memberikan penyuluhan hukum, khususnya dalam pembuatan akta, sehingga masyarakat akan mendapatkan perlindungan hukum dan kepastian hukum, sehubung dengan semakin meningkatnya proses pembangunan sehingga meningkat pula kebutuhan hukum dalam masyarakat. ${ }^{2}$

Notaris mengeluarkan produk hukum, salah satunya Akta yang dibuat oleh Notaris, dimana akta otentik yang dibuat oleh atau di hadapan Notaris menurut bentuk dan tata cara telah ditetapkan didalam Pasal 1 angka 7 UUJN. Akta yang dibuat menguraikan secara otentik mengenai semua perbuatan, perjanjian dan penetapannya yang disaksikan oleh para penghadap dan saksi-saksi. Dengan adanya akta otentik yang dibuat Notaris, dapat menjamin hak dan kewajiban dari para pihak yang mengadakan perjanjian sehingga apabila dikemudian hari, disalah satu pihak terjadinyapelanggaran dari isi perjanjian tersebut maka dapat dikenakan sanksi atau hukuman yang sebelumnya telah disepakati didalam perjanjian tersebut.

Menurut Habib Adjie, Notaris merupakan suatu jabatan publik yang mempunyai karakteristik yaitu sebagai Jabatan, artinya UUJN merupakan unifikasi di bidang pengaturan jabatan Notaris, artinya satu-satunya aturan

${ }^{1}$ Kelik Pramudya dan Ananto Widiatmoko, Pedoman Etika Profesi Aparat Hukum, Pustaka Yusticia, Yogyakarta, 2010, hlm. 110.

${ }^{2}$ Santia Dewi dan R.M. Fauwas Diradja, Paduan teori dan Praktik Notaris. Pustaka Yusticia, Yogyakarta, 2011, hlm. 8 . 
hukum dalam bentuk undang-undang yang mengatur Jabatan Notaris di Indonesia, sehingga segala hal yang berkaitan dengan Notaris di Indonesia harus mengacu kepada UUJN. Jabatan Notaris merupakan suatu lembaga yang diciptakan oleh negara. Menempatkan Notaris sebagai jabatan merupakan suatu bidang pekerjaan atau tugas yang sengaja dibuat oleh aturan hukum keperluan dan fungsi tertentu (kewenangan tertentu) serta bersifat berkesinambungan sebagai suatu lingkungan pekerjaan tetap. ${ }^{3}$

Dalam bertindak dan bertugas dalam pembuatan akta Notaris, notaris harus menjaga kepentingan para pihak yang terkait didalam perbuatan hokum tersebut, serta menjamin kerahasiaan isi akta yang menyangkut kepada kepentingan para pihak yang melakukan perbuatan hukum tersebut.Notaris harus mempunyai integritas moral, dalam artian harus melandasi pelaksanaan tugas secara profesional. Sesuatu hal yang bertentanganyang tidak baik harus dihindari walaupun dengan melakukan hal tersebut, ia akan memperoleh imbalan jasa yang tinggi. Perimbangan moral dalam melaksanakan tugas profesi tersebut, harus diselaraskan dengan nilai-nilai dalam masyarakat, sopan santun, dan agama. Seorang Notaris itu berarti apabila ia menjadiseseorang yang bermoral dalam mengerjakan pekerjaannya serta mengedepankan sikap profesionalitasnya. Karena dalam masalah pertanggung jawaban seorang Notaris merupakan hal yang utama mengingat akta yang ia buat merupakan bukti yang kuat sebagai alat bukti tertulis. Memiliki pedoman berupa UUJN dan juga Kode Etik yang menjadi landasan Notaris dalam melakukan segala tugas, kewenangan, hak, kewajiban, hingga larangan yang disertai sanksi hukum bagi Notaris.

Dimana dari hal pembuatan sebuah akta bisa menjadi kepercayaan penghadap terhadap Notaris akan pengurusan hal-hal lainnya. Mulai dari perbantuan penasihat perceraian, dimana nantinya juga akan adanya pembuatan perjanjian perkawinan atau pembagian harta gono-gini, pengurusan pajak, mengurusi wasiat hingga selesai nya dari isi wasiat tersebut, dengan kata lain bisa menjadi orang kepercayaan penghadap selain keluarganya sendiri, berperan sebagai ajang tukar pikiran hingga permasalahan pribadi yang sepatutnya tidak diketahui oleh Notaris itu sendiri.

Hal ini lah kemudian menimbulkan sebuah konflik internal, baik di Institusi Pemerintah ataupun dikalangan para Notaris itu sendiri. Dikarenakan dasar hukum mengenai keberadaan Notaris/lembaga notariat terdapat pada Buku

3Sutrisno, "Tanggapan Terhadap Undang-undang No.30 Tahun 2004 tentangJabatan Notaris", Bahan Kuliah pada Kuliah Etika Profesi Notaris Magister Kenotariatan Universitas Sumatera Utara, Medan, 2007, hlm. $9-10$. 
keempat KUHPerdata tentang Pembuktian dan Daluarsa, dimana dalam pembuktian dikenal dengan adanya alat bukti tertulis, alat bukti tertulis yang paling kuat adalah berbentuk akta otentik. Adapun yang dimaksudkan dengan akta otentik dalam Pasal 1868 KUHPerdata adalah sebagai berikut: "Suatu akta otentik ialah suatu akta yang di dalam bentuk yang ditentukan oleh undang-undang, dibuat oleh atau dihadapan pegawai-pegawai umum yang berkuasa untuk itu ditempat dimana akta dibuat."4

Kewenangan tersebut selanjutnya dijabarkan oleh Pasal 1 angka 1 UUJN yang mulai berlaku 6 Oktober 2004, yang sebelum undang-undang ini lahir, kewenangan tersebut diatur dalam Notaris Reglement S. 1860 No. 3. Adapun bunyi Pasal 1 angka 1 UUJN adalah sebagai berikut: "Notaris adalah pejabat umum yang berwenang untuk membuat akta otentik dan kewenangan lainnya sebagaimana dimaksud dalam Undang-Undang ini."5

Apabila para penghadap memberi kuasa untuk melakukan suatu pekerjaan tertentu untuk dan atas nama pemberi kuasa, para penghadap datang kepada Notaris harus karena keinginan para penghadap sendiri, dan pada dasarnya semua Notaris terbuka untuk siapa saja, dan juga suatu hal tidak tepat jika tiap orang yang datang kepada Notaris terlebih dahulu harus membuat perjanjian pemberian kuasa untuk melakukan suatu pekerjaan tertentu. Dengan tidak adanya perjanjian baik tertulis atau lisan yang dinyatakan secara tegas atau tidak antara Notaris dengan para pihak untuk membuat akta yang diinginkannya, maka tidak tepat jika hubungan hukum antara Notaris dan para pihak dikualifikasikan sebagai hubungan kontraktual yang jika Notaris wanprestasi dapat dituntut digugat dengan dasar gugatan Notaris telah wanprestasi. ${ }^{6}$

Ketika penghadap datang ke Notaris agar tindakan atau perbuatannya diformulasikan ke dalam akta otentik sesuai dengan kewenangan Notaris, dan kemudian Notaris membuat akta atas permintaan atau keinginan para penghadap tersebut, maka dalam hal ini memberikan landasan kepada Notaris dan para penghadap telah terjadi hubungan hukum. ${ }^{7}$

Biasanya disinilah awal terjadinya sebuah titipan pekerjaan tambahan kepada Notaris itu sendiri, ketika seorang penghadap datang ke Notaris untuk melakukan sesuatu hal, maka biasanya penghadap mempercayai semua pekerjaan administrasi kepada Notaris itu sendiri, sehingga bagi institusi lainnya tentu hal ini agak mengganggu dikarnakan beberapa instansi pemerintah

4Kitab Undang-Undang Hukum Perdata (Burgerlijk Wetboek), Pasal 1868.

5Undang-Undang Nomor 30 Tahun 2004 tentang Jabatan Notaris, LN No. 117 Tahun 2004, TLN No. 4432, Pasal 1 Angka 1.

${ }^{6}$ Habib Adjie, Hukum Notaris Indonesia Tafsir Tematik Terbadap UU No. 30 Tabun 2004 tentang Jabatan Notaris, Reflika Aditama, 2008, hlm. 17.

${ }^{7}$ Ibid. 
mengharapkan kepengurusan dokumen dengan orang yang bersangkutan dan tidak diwakilkan oleh melalui kantor Notaris, sehingga meninggalkan kesan yang tidak baik bagi Notaris karna mengerjakan sesuatu yang berada diluar kewenangan dan tugas nya yang telah diatur oleh UUJN. Sementara disisi lain, karna unsur kepercayaan kepada Notaris lah, dan para penghadap yang awam atau tidak biasa dengan birokrasi dan administrasi yang mereka anggap sesuatu yang merepotkan dan juga memerlukan waktu yang cukup lama kepengurusannya, membuat para penghadap serta merta memberikan proses kepengurusannya kepada Notaris, karna Notaris dianggap sudah biasa menggurusi hal tersebut dan tahu akan seluk beluk kepengurusannya.

Ada beberapa pekerjaan bagi seorang Notaris yang sering diserahkan kepengurusannya oleh para penghadapnya dan rata-rata pekerjaan tersebut berhubungan dengan administrasi dan langsung berhadapan dengan pemerintah, dengan birokrasi yang panjang dan membuang waktu dan tenaga, menjadi alasan tersendiri bagi para penghadap untuk lebih diserahkan kepengurusan permasalahan administrasi tersebut kepada Notaris yang telah ia percayai. Ada yang berhubungan dengan admisnistrasi, perizinan, hingga pembayaran pajak yang mana uang nya tidak lah dalam jumlah sedikit. Adapun beberapa rincian permasalahan nya adalah sebagai berikut: Pertama, administrasi kepengurusan balik nama, penurunan hak ataupun peningkatan hak, sertifikat tanah di Badan Pertanahan Nasional, yang notabene merupakan pekerjaan seorang Pejabat Pembuat Akta Tanah (PPAT); Kedua, perizinan administrasi untuk CV dan PT pada instansi terkait, misalnya izin keterangan domisili pada kelurahan, NPWP pada kantor pajak, Surat Izin Usaha Perdagangan (SIUP) dan Tanda Daftar Perusahaan (TDP) di Dinas Perindustrian dan Perdagangan yang mana itu bukan lah merupakan kewenangan hak kerja seorang Notaris, tetapi malah diserahkan kepengurusannya kepada Kantor Notaris padahal yang bersangkutan bisa langsung melaksanakan kepengurusan administrasi tersebut sendiri tanpa adanya bantuan Notaris.

Maka dari itu penulis lebih memilih untuk mengulas dua permasalahan yang paling sering diserahkan kepengurusannya dan dikerjakan oleh Notaris itu sendiri, yaitu administrasi di Badan Pertanahan Nasional dan Kantor Pajak, yang mana sebenarnya kepengurusan administrasi ini bisa diurus sendiri ketimbang diserahkan kepengurusannya kepada Notaris.

Berdasarkan uraian tersebut di atas, penting untuk diteliti dan dikaji lebih lanjut mengenai hal tersebut dengan judul Tesis yang diangkat oleh peneliti 
adalah "Implikasi Hukum Terhadap Notaris Yang Memberikan Jasa Kenotariatan Di Luar Kewenangannya."

\section{Rumusan Masalah}

Berdasarkan latar belakang yang diuraikan diatas, maka yang menjadi pokok permasalahan dalam penelitian ini: Pertama, apakah implikasi hukum dan pertanggungjawaban notaris terhadap jabatannya dalam melaksanakan hal yang berada diluar kewenangannya? dan Kedua, bagaimana pandangan Majelis Pengawas Wilayah (MPW) Dan Majelis Pengawas Daerah (MPD) terhadap notaris yang menjalankan hal yang berada di luar kewenangannya?

\section{Tujuan Penelitian}

Adapun tujuan dari penelitian ini: Pertama, untuk mengetahui dan menganalisa implikasi hukum dan pertanggungjawaban notaris terhadap jabatannya dalam melaksanakan hal yang berada di luar kewenangannya, bagaimana pandangan dan pendapat MPD dan MPW terhadap notaris yang melaksanakan diluar kewenangannya. Kedua, untuk mengetahui dan menganalisa bagaimana pandangan dan langkah apa yang akan diambil oleh Majelis Pengawas Wilayah (MPW) Dan Majelis Pengawas Daerah (MPD) terhadap Notaris yang melakukan pelanggaran diluar kewenangannya.

\section{Metode Penelitian}

Jenis penelitian yang digunakan adalah penelitian yuridisempiris atau penelitian hukum sosiologis. Penelitian yuridis empiris dilakukan dengan cara mengadakan identifikasi hukum dan bagaimana efektifitas hukum yang berlaku dalam masyarakat. ${ }^{8}$ Pendekatan yuridis digunakan untuk menganalisa berbagai peraturan tentang jabatan Notaris, sedangkan pendekatan empiris dipergunakan untuk menganalisis hukum yang dilihat dari perilaku masyarakat dalam kehidupan bermasyarakat, selalu berinteraksi dan berhubungan dengan aspek kemasyarakatan. ${ }^{9}$

1. Pendekatan Perundang-Undangan, karena yang akan diteliti adalah berbagai aturan hukum yang menjadi fokus sekaligus tema sentral suatu penelitian. ${ }^{10}$ Pendekatan Undang-Undang dilakukan dengan menelaah

${ }^{8}$ H. Zainuddin Ali, Metode Penelitian Hukum, Sinar Grafika, Jakarta, 2010, hlm. 12.

${ }_{9}^{9}$ Bambang Sunggono, Metodologi Penelitian Hukum, PT Raja Grafindo Persada, Jakarta, 2003, hlm. 43.

${ }_{10}$ Mukti Fajar Achmad dan Yulianto. Dualisme Penelitian Hukum Normatif dan Empiris. Pustaka Pelajar, Yogyakarta, 2010, hlm. 302. 
semua Undang-Undang dan regulasi yang bersangkutan dengan masalah hukum yang sedang diteliti. ${ }^{11}$

2. Pendekatan Konseptual ini beranjak dari pandangan-pandangan dan doktrin-doktrin yang berkembang di dalam ilmu hukum dengan menggunakan pendekatan ini pemahaman akan pandangan-pandangan serta doktrin-doktrin akan menjadi sandaran untuk peneliti dalam membangun argumentasi hukum.

\section{Hasil Penelitian dan Pembahasan}

Tugas pokok dari Notaris ialah membuat akta-akta otentik dan adapun akta otentik itu menurut Pasal 1870 KUHPerdata memberikan kepada pihak-pihak yang membuatnya suatu bukti yang sempurna tentang apa yang dimuat di dalamnya. Dalam hal ini surat yang sebagai alat pembuktian tertulis dibedakan dalam akta dan surat bukan akta dimana dalam hal ini Akta juga dapat dibedakan kedalam akta otentik dan akta di bawah tangan. Perbedaan pokok antara akta otentik dengan akta di bawah tangan adalah cara pembuatan atau terjadinya akta tersebut. Jadi suatu akta otentik ialah suatu akta yang dibuat dalam bentuk yang telah ada serta ditentukan undang-undang oleh dan ataupun di hadapan pejabat umum yang berwenang untuk itu (seperti Notaris, Hakim, Panitera, Juru Sita, Pegawai Pencatat Sipil), di tempat akta itu dibuat. ${ }^{12}$

Sedangkan akta di bawah tangan cara pembuatan atau terjadinya tidak dilakukan oleh dan atau di hadapan pejabat pegawai umum, tetapi cukup oleh pihak yang berkepentingan saja. ${ }^{13}$ Akta otentik mempunyai arti yang lebih penting daripada sebagai alat bukti, bila terjadi sengketa maka akta otentik dapat digunakan sebagai pedoman bagi para pihak yang bersengketa.

Notaris yang masih berada diluar jalur serta tidak melaksanakan hal yang berada di luar kewenangannya atau masih berada didalam lingkup tataran hukum yang ada, akan selalu ada masalah yang mengintainya, tetapi dikarnakan ia tetap berada dijalurnya, maka akan mudah mencari solusinya walaupun tetap jadi beban pikirannya karna jika ia tidak hati-hati dalam menjalani suatu kasus, maka dari yang awal nya benar, bisa menjadi salah. Hal paling sering timbul adalah dari Ketidak hati-hatian secara normatif dan dari dipermasalahkannya notaris oleh pihak lain, baik kliennya atau berasal dari luar pekerjaannya.

\footnotetext{
${ }^{11}$ M. Syamsudin, Operasionalisasi Penelitian Hukum, PT Raja Grafindo Persada, Jakarta, 2007, hlm. 58.

${ }^{12}$ Pasal 1868 KUHPerdata

13Pasal 1874 KUHPerdata
} 
Biasanya produk notaris yang paling sering bermasalah dan berperkara baik di pengadilan ataupun dipihak kepolisian adalah:

1. Akta yang dibuat dalam kondisi para pihak yang tidak saling berhadapan, atau hanya salah satu pihak saja yang menghadap. Hal ini lah biasanya yang menjadi awal duduk perkara yang akan menghadang si notaris kedepannya, bisa jadi akan terjadinya laporan akibat kerugian yang diderita oleh salah satu pihak. Dalam hal ini bisa jadi Notaris melakukan suatu kesalahan dalam pembuatan akta. Kesalahankesalahan yang mungkin dapat terjadi, yaitu:

a. Kesalahan ketik pada salinan Notaris, dalam hal ini kesalahan tersebut dapat diperbaiki dengan membuat salinan baru yang sama dengan yang asli dan hanya salinan yang sama dengan yang asli baru mempunyai kekuatan sama seperti akta asli.

b. Kesalahan bentuk akta Notaris, dalam hal ini dimana seharusnya dibuat berita acara rapat tapi oleh Notaris dibuat sebagai pernyataan keputusan rapat.

c. Kesalahan isi akta Notaris, dalam hal ini mengenai keterangan dari para pihak yang menghadap Notaris, di mana saat pembuatan akta dianggap benar tapi ternyata kemudian tidak benar. ${ }^{14}$

2. Data identitas yang di palsukan dengan keterangan salah satu pihak atau bahkan di kedua belah pihak memberikan keterangan ataupun data palsu, sehingga dalam hal ini notaris dianggap telah menerbitkan akta palsu. Data objek yang tidak valid atau tidak sesuai fakta yang ada, biasanya hal ini terjadi dalam perjanjian kerja sama dan jual beli, sehingga timbulnya wanprestasi oleh salah satu pihak.

Biasanya awal permasalahannya ini tidak berawal dari akta atau produk notaris itu sendiri, tetapi hal ini berawal dari proses atau prosedur yang dilakukan oleh si notaris itu sendiri, dan apabila terbukti dikemudian hari pada saat pengadilan, maka notaris tersebut dapat diajukan gugatan kepadanya, dan si notaris wajib bertanggung jawab sepenuhnya, dimana secara hukum pidana termasuk dalam penipuan karna tidak menuliskan fakta yang sebenarnya serta bisa dijatuhi sanksi administratif oleh Majelis Pengawas Notaris dan Sanksi Kode Etik oleh Majelis Pengawas Notaris dan Sanksi Kode Etik Notaris oleh Dewan Kehormatan Notaris.

Pertanggung jawaban seorang notaris yang bergerak diluar kewenangannya, wajib bertanggung jawab atas semua aspek formalitas akta atau produk yang ia buat oleh dan dihadapannya. Sebenarnya, kedudukan notaris yang di jelaskan seperti pasal-pasal di atas, menunjukkan sebenarnya notaris bukanlah sebagai pihak yang bisa masuk dan diikut sertakan kedalam tergugat

${ }^{14}$ Mudofir Hadi, "Pembatalan Isi Akta Notaris Dengan Putusan Hakim”, Varia Peradilan, No. 72, 1991, hlm. 142-143. 
baik secara pidana ataupun perdata, karna apabila terjadi sebuah sengketa diantara mereka terhadap akta notaris yang mereka buat ketika berhadapan dengan notaris tersebut, akta tersebut telah menjadi sebuah bukti otentik. Sebenarnya notaris bisa mengatasi hal sebagai mana di jelaskan diatas, karna notaris wajib melindungi dirinya sendiri denngan menjalankan tugas dan wewenangnya dengan baik dan benar peruntukkannya sesuai dengan UndangUndang Jabatan Notaris dan Peraturan Perundang-Undangan lainnya.

Notaris hanya dapat dijadikan tersangka yang sesuai dengan aturan hukum apabila ia dengan sengaja membuat sebuah akta palsu dengan sesuai keinginan ataupun tidak dengan keinginan si penghadap, jadi ia dapat dengan turut dianggap telah melakukan kejahatan, yang mana sebenarnya notaris dikatakan tidak boleh menolak membuat suatu akta yang dimohon serta notaris tidak boleh membuat suatu akta yang bertentangan dengan hukum.

Berdasarkan hal di atas, dapat ditarik kesimpulan bahwa, apabila notaris menyalahgunakan jabatannya, dan terbukti melakukannya maka dapat dikenai sanksi berupa sanksi administratif berupa peringatan tertulis, pemberhentian sementara, pemberhentian dengan hormat, pemberhentian dengan tidak hormat atau juga sanksi pidana berupa pidana penjara atau bisa jadi menerima dua hukuman sekaligus, yaitu hukuman penjara dan sanksi administratif.

Dengan penjelasan di atas dapa pula ditarik bahwa apabila Pejabat atau Notaris telah melakukan pelanggaran asas spesialitas, akan menerimasanksi dari penyalahgunaan jabatan notaris baik sanksi perdata dan sanksi administrasi dijatuhkan terhadap jabatan notaris, berlaku terhadap Jabatan PPAT (Pejabat Pembuat Akta Tanah), dengan sanksi yang diterima bisa ganti rugi, pemberhentian sementara dari jabatannya ataupun diberhentikan secara tidak hormat, sesuai dengan isi Pasal 9 Undang-Undang Jabatan Notaris dan Pasal 12 Undang-Undang Jabatan Notaris, dengan penafsiran sistematis, dimana metode ini adalah penafsiran peraturan perundang-undangan dengan menghubungkannya dengan peraturan hukum (Undang-Undang) lainnya atau bisa juga dengan keseluruhan sistem hukum. Berbeda apabila seorang Notaris menerima hukuman penjara, maka secara otomatis bisa jadi akan menerima dua hukuman sekaligus, yaitu hukuman penjara dan kehilangan jabatan Pejabat Pembuat Akta Tanah (PPAT), yang secara otomatis apabila seseorang mendapat hukuman penjara, secara otomatis juga ada beberapa hak kewarganegaraannya yang ikut juga dibatasi, contohnya hak memilih dan dipilih (dalam hal ini berkaitan dengan pemilihan umum), hak memegang jabatan publik (dalam hal ini jabatan PPAT). 
Sebenarnya, dasar hukum untuk menjadikan seorang notaris sebagai tersangka dalam melakukan hal yang berada di luar kewenangannya ketika membuat akta pada dasarnya tidak ada diatur, bagaimana notaris menjalankan tugas dan jabatannya sebagai tersangka dalam kasus pidana apakah masih bisa melanjutkan jabatannya atau terputus begitu saja ketika ditetapkan sebagai tersangka. Apabila seorang notaris dalam status tersangka, seharusnya secara otomatis harus mundur dari jabatannya, sesuai dengan hati nuraninya, walaupun tidak ada norma yang jelas mengatur mengenai hal ini, semua tergantung kepada hati nuraninya, walaupun tidak ada yang menghalanginya dalam hal ini pembuatan aktanya didalam kewenangannya, walaupun seharusnya kalaupun seorang pejabat yang kondisinya telah menjadi seorang tersangka, harus berhenti dari jabatannya, jadi seorang notaris secara otomatis sebaiknya harus berhenti juga dari jabatannya, karna notaris adalah seorang pejabat umum, hal ini merupakan suatu implikasi dari perbuatan yang ia lakukan, walaupun sebenarnya harus mengedepankan asas praduga tak bersalah (Presumptionsof Innocence) karna belum tentu notaris yang telah menjadi seorang tersangka benarbenar bersalah dimana putusan pengadilan lah yang menentukan seseorang itu salah atau tidak. Akan tetapi walaupun sudah ditetapkan status tersangkanya, semuanya kembali dan tergantung atas dan dari masyarakat itu sendiri, apakah masih mau menggunakan jasa notaris tersebut apa tidak.

Penjatuhan sanksi administratif tidak serta merta menjadikan atau mengakibatkan akta yang dibuat oleh dan dihadapannya menjadi suatu akta dibawah tangan atau akta yang batal demi hukum, hal ini dikarenakan penjatuhan sanksi administratif yang dijatuhkan kepadanya tidak ada kaitannya segala aspek yang dimiliki oleh akta notaris tersebut, baik aspek lahir, aspek formil dan aspek materiil akta notaris tersebut.

Dalam hukum perdata, penjatuhan sanksi yang diberikan kepada akta seorang notaris yang dibuat oleh dan dihadapan Notaris menjadikan akta tersebut memiliki kekuatan pembuktian sebagai akta dibawah tangan atau akta tersebut batal demi hukum, begitu juga dalam hukum pidana, kalau seandainya notaris tersebut dijatuhi sanksi pidana tidak juga serta merta menjadikan atau mengakibatkan akta yang dibuat oleh dan dihadapannya menjadi batal demi hukum. Mempidanakan Notaris dengan alasan-alasan yang menyangkut dengan aspek formal akta, tidak juga serta merta membatalkan akta notaris yang dijadikan objek perkara pidana tersebut, akta tersebut tetap mengikat para pihak yang terdapat di dalamnya.

Apabila juga dijatuhkan sanksi etika terhadap notaris tidak juga serta merta membuat akta tersebut menjadi sebuah akta di bawah tangan, batal demi hukum, 
ataupun para pihak ingin membatalkan akta notaris yang dibuat oleh dan dihadapan Notaris, akta tersebut tetap mengikat para pihak yang terdapat di dalamnya dan notaris hanya bertanggung jawab dengan melaksanakan sanksi hukum dan etika akibat dari penjatuhan sanksi Hukum dan Etika yang diberikan kepadanya.

\section{Penutup}

Dari hasil penelitian di atas, dapat ditarik kesimpulan bahwa: Pertama, apabila seorang notaris yang bergerak di luar kewenangannya dan terbukti telah melakukan pelanggaran dan bergerak di luar kewenangannya, wajib bertanggung jawab atas semua aspek formalitas akta atau produk yang ia buat oleh dan dihadapannya. Hal ini dikarenakan seorang Notaris memiliki tanggung jawab yang berdasarkan kesalahan (based on fault of liability), dimana dalam hal ini notaris harus bertanggung jawab pada kesalahan atau pelanggaran yang buat secara sengaja pada akta autentik yang ia kerjakan atau yang ia buat.

Berdasarkan juga pembahasan pada bab 2 di atas, dapat ditarik kesimpulan bahwa, apabila notaris menyalahgunakan jabatannya, dan terbukti melakukannya maka dapat dikenai sanksi berupa sanksi administratif berupa peringatan tertulis, pemberhentian sementara, pemberhentian dengan hormat, pemberhentian dengan tidak hormat atau juga sanksi pidana berupa pidana penjara atau bisa jadi menerima dua hukuman sekaligus, yaitu hukuman penjara dan sanksi administratif.

Jadi apabila Notaris telah melakukan pelanggaran asas spesialitas, dengan hal tersebut menunjukkan bahwa adapun sanksi dari penyalahgunaan jabatan notaris baik sanksi perdata dan sanksi administrasi dijatuhkan terhadap jabatan notaris, berlaku terhadap Jabatan PPAT, dengan sanksi yang diterima bisa ganti rugi, pemberhentian sementara dari jabatannya ataupun diberhentikan secara tidak hormat.

Penjatuhan sanksi administratif tidak serta merta menjadikan atau mengakibatkan akta yang dibuat oleh dan di hadapannya menjadi suatu akta di bawah tangan atau akta yang batal demi hukum, hal ini dikarenakan penjatuhan sanksi administratif yang dijatuhkan kepadanya tidak ada kaitannya segala aspek yang dimiliki oleh akta notaris tersebut, baik aspek lahir, aspek formil dan aspek materiil akta notaris tersebut.

Dalam hukum perdata, penjatuhan sanksi yang diberikan kepada akta seorang notaris yang dibuat oleh dan dihadapan Notaris menjadikan akta tersebut memiliki kekuatan pembuktian sebagai akta di bawah tangan atau akta 
tersebut batal demi hukum, begitu juga dalam hukum pidana, kalau seandainya notaris tersebut dijatuhi sanksi pidana tidak juga serta merta menjadikan atau mengakibatkan akta yang dibuat oleh dan dihadapannya menjadi batal demi hukum.

Memidanakan Notaris dengan alasan-alasan yang menyangkut dengan aspek formal akta, tidak juga serta merta membatalkan akta notaris yang dijadikan objek perkara pidana tersebut, akta tersebut tetap mengikat para pihak yang terdapat didalamnya.

Kedua, penerapan pengawasan dan pembinaan yang telah dilakukan oleh Majelis Pengawas Notaris khususnya Majelis Pengawas Daerah Kota Pekanbaru sebagai pengawas dan pembina yang langsung berhadapan dengan Notaris hampir dapat dilakukan dengan sempurna, dengan catatan bahwa saling terbuka dan saling memberikan komunikasi yang jelas antar Majelis Pengawas Pusat (MPP), Majelis Pengawas Wilayah (MPW), Majelis Pengawas Daerah (MPD) hingga ke Notaris itu sendiri itu sangat penting guna menghindari miskomunikasi serta untuk menciptakan sinergi yang baik dalam penerapan pengawasan yang dilakukan oleh Majelis Pengawas, serta juga harus juga tetap berada pada lajur koridor kewenangan yang dimiliki oleh masing-masing Majelis Pengawas.

Pengawasan ini harus dilakukan agar para Notaris tidak ke luar dari jalur dan melanggar peraturan yang telah dikeluarkan oleh Undang-Undang Jabatan Notaris atau peraturan lainnya. Karena Notaris memiliki prinsip bertanggung jawab yang berdasarkan pada kesalahan yang ia buat (based on fault of liability), dimana dalam hal ini Notaris harus bertanggung jawab pada kesalahan atau pelanggaran yang disengaja pada akta autentik yang dia buat dikantornya.

Tetapi ada juga sebenarnya faktor yang menjadi penghambat dalam penerapan pengawasan dan pembinaan ini, salah satunya dikarnakan faktor kurang sebandingnya antara pengawas dan Notaris yang tersebar, juga luas wilayah tersebarnya kantor Notaris itu menjadikan kurang efektifnya waktu apabila harus mengawasi semuanya sekaligus juga kurangnya perhatian pemerintah daerah ataupun pusat dengan profesi notaris.

Kurangnya perhatian pemerintah pada peraturan peraturan terkait jabatan Notaris yang dianggap tidak melindungi profesi Notaris, kurangnya kepastian hukum akan akta yang dibuat dinilai kurang melindungi masyarakat yang terlibat di dalam akta tersebut.

Dan juga kurang sesuainya pelaksanaan kewenangan Majelis Pengawas Daerah Kota Pekanbaru dengan yang ada dalam Undang-Undang Jabatan Notaris, hal ini dikarenakan berdasarkan pada Undang-Undang Jabatan Notaris 
Pasal 15 ayat (2) huruf $f$ dan juga merujuk pada nota kesepahaman antara Polisi Republik Indonesia terutama dari pihak penyidik yang mengirim surat permintaan penyidikan. Hal ini juga termasuk akan pengawasan yang dilakukan Majelis Pengawas Daerah juga melakukan pengawasan Notaris selaku PPAT di dalam jabatannya.

Adanya ketidaksesuaian penetapan jadwal pemeriksaan, persidangan, alokasi dana khusus yang disiapkan pemerintah terkait akan pelaksanaan tugas dan kewenangan dari Majelis Pengurus Daerah, hingga rangkap jabatan yang dimiliki masing-masing anggota Majelis Pengawas Daerah membuat pengawasan sebenarnya kurang efektif.

Adapun saran yang akan penulis berikan sesuai dengan permasalahan yang diuraikan adalah sebagai berikut: Pertama, walaupun seorang Notaris dasarnya memang tahu hukum dan sadar akan hukum, tetapi sebenarnya perlunya akan penekanan lagi serta penanaman akan nilai Undang-Undang Jabatan Notaris, agar tidak ke luar dari kewenangan yang seharusnya harus dijalankan oleh Notaris, dikarenakan godaan akan hasil yang besar apabila seorang Notaris bergerak di luar kewenangannya. Kedua, perlunya pendampingan hukum seorang ahli hukum kenotariatan dalam setiap pemeriksaan ataupun persidangan yang menghadirkan seorang Notaris agar tidak salah dalam memberikan keterangan yang akan menjerumuskan nya ke dalam sebuah hukuman, baik secara pidana, perdata atau secara sanksi administrasi, karna belum tentua awal sebuah permasalahan ini dari pihak Notarisnya sendiri. hal ini juga karna sebenarnya notaris bukanlah sebagai pihak yang bisa masuk dan diikut sertakan kedalam tergugat baik secara pidana ataupun perdata. Ketiga, pentingnya penguatan lembaga Majelis Pengawas Daerah, agar temuan dari investigasi yang didapatkan Majelis Pengawas Daerah ini dapat lebih mempengaruhi hasil sidang, hal ini diperlukan demi mendapatkan keadilan yang lebih baik bagi semua pihak yang terlibat. Keempat, pemerintah harus lebih mengedepankan jaminan akan kepastian hukum yang memiliki nilai dan bobot yang dapat dipertanggung jawabkan dari produk yang dikeluarkan dari Notaris, hal ini harus diwujudkan demi kenyamanan masyarakat selaku para pengguna jasa Notaris. Kelima, pemerintah harus menaruh perhatian lebih agar mendukung pengawasan, karna selama ini tidak adanya perhatian pemerintah untuk penunjang kegiatan pengawasan yang dilakukan, mulai dari faktor prasarana, honorarium, susahnya penetapan jadwal pemeriksaan serta luas wilayah dan banyak Notaris tidak sebanding dengan jumlah anggota pengawas. Keenam, pemerintah harus memberikan anggaran keuangan khusus untuk kepentingan Majelis Pengawas 
demi melakukan tugas dan wewenangnya, minimnya anggaran dana tersedia membuat pelaksanaannya tidak berjalan efektif dan maksimal. Ketujuh, menghindari rangkap jabatan bagi para anggota Majelis Pengawas, karena anggota yang rangkap jabatan mempengarihi kinerja para anggota pengawas karna harus berbagi waktu dan pikiran.

\section{Daftar Pustaka}

\section{Buku}

Achmad, Mukti Fajar dan Yulianto. Dualisme Penelitian Hukum Normatif dan Empiris, Pustaka Pelajar, Yogyakarta, 2010.

Adjie, Habib, Hukum Notaris Indonesia Tafsir Tematik Terhadap UU No. 30 Tahun 2004 tentang Jabatan Notaris, Reflika Aditama, Bandung, 2008.

Ali, H. Zainuddin, Metode Penelitian Hukum, Sinar Grafika, Jakarta, 2010.

Dewi, Santia dan R.M. Fauwas Diradja, Paduan teori dan Praktik Notaris, PustakaYusticia, Yogyakarta, 2011.

Pramudya, Kelik dan Ananto Widiatmoko, Pedoman Etika Profesi Aparat Hukum, Pustaka Yusticia, Yogyakarta, 2010.

Soekanto, Soerjono, Pengantar Penelitian Hukum, UI Press, Jakarta, 1986.

Sunggono, Bambang, Metodologi Penelitian Hukum, Raja Grafindo Persada, Jakarta, 2003.

Syamsuddin, M., Operasionalisasi Penelitian Hukum, PT Raja Grafindo Persada, Jakarta, 2007.

Makalah

Sutrisno, "Tanggapan Terhadap Undang-undang No.30 Tahun 2004tentangJabatan Notaris", Bahan Kuliah pada Kuliah Etika Profesi Notaris Magister Kenotariatan Universitas Sumatera Utara, Medan, 2007.

\section{Majalah}

Hadi, Mudofir, "Pembatalan Isi Akta Notaris Dengan Putusan Hakim", Varia Peradilan, No. 72, 1991.

\section{Peraturan Perundang-Undangan}

Kitab Undang-Undang Hukum Perdata (Burgerlijk Wetboek).

Undang-UndangNomor 30 Tahun 2004Tentang Jabatan Notaris, Lembaran Negara Republik Indonesia No. 117Tahun 2004, Tambahan Lembaran Negara Republik Indonesia No. 4432. 